\title{
An Analysis on William Ernest Henley's Invictus
}

\author{
Ayu Malinda \\ English Educational Departement, PGRI Universitay of Banyuwangi
}

Received : Tuesday, April 3, 2018

Revised : Friday, April 6, 2018

Accepted : Tuesday, April 24, 2018

\section{Abstract}

The research is an analysis the poem structure of William Ernest Henley Invictus. The purpose of this research is to understand the structure that used in the poem of William Ernest Henley Invictus. The data were taken from documentation of Invictus poem and biographical of the poet. The researcher used objective approach as data analysis method. The structure of poetry is consisting of two structures, namely; physical structure and inner structure. The physical structure is consisting of six sections, they are diction, imagery, concrete word, figurative language, version and typography. While, the inner structure is divide on four proportion they are theme, tone, feeling and mandate. To make a good poetry the poet should pay attention in the elements of poetry, especially the structure of poetry.

Keywords:Analysis; invictus, structure and William Ernest Henley

\section{A. Introduction}

Some people write the beautiful words just to convey their feeling or information by song, novel and poetry. Poetry is one of media that commonly used to convey information or feeling by the beautiful word and is an interesting study material to be examined given the many languages in it.

Poetry is one of media for expressing personal stories as lived experiences (social and psychological experiences. Thus, poetry as a creative writing genre is not merely a form of literary work. It a social space for enacting psychologically laden social practices that someone experience as a routine story. As Cermin (2009), poetry writing involves effect, intention, integrates, personal history and future actions. Thus, in crafting poetry, he has manipulated and make sense of the language he used in his work. Poetry is used to express whatever he wants or needs as result of his lived experience in poetry writing and his capabilities of manipulating the language or creating new and acceptable terminologies in his poetry writing.

\section{Research Problem}

Based on the background above, researcher formulate the research problem as follow:

What is the structure of invictus? 


\section{Objective of the research}

Based on the problem, the objective of the research is to understand the structure that used in the poem of William Ernest Henley Invictus.

\section{3. the significance of the Research}

the result of the research was expected can be useful for the readers and the other researchers:

a. For readers

The action giver were useful for readers to know the structure of the poetry and the reflected life in the poem by analyzing William Ernest Henley's Invictus

b. For the Other Researchers

It can be used as a references or alternative source

\section{B. Poetry}

Waluyo argues that poetry is a form of literature that expresses the poet's thoughts and feelings imaginatively and is composed by concentrating all the power of language by concentrating the physical structure and inner structure (2003). In poetry there are structures that compile it. These structures include the physical and inner structures. Physical structure is so-called the linguistic structure while the inner structure is the inner expression of the author.

Paul (2005) states that poets always write as tuned to rhythm, imagery, and feeling. Every phrase, every sentence, is carefully balanced so that it is held in perfect tension with the structure as a whole he added that poetry consists of rhythm, imagination, and feelings Have a balanced structure Like a circle. Referring to that opinion in the poem is present Structures that build them equally. It is intended for poetry Has a beauty that can be enjoyed by the reader.

Waluyo argues that the physical structure of poetry consists of diction, counseling, concrete words, assignments, versions, and typography. While the inner poetic structure consists of: theme, tone, feeling, and mandate (2003: 28)

\section{Physical Structure of Poetry}

The physical structures of poetry is in the forms of diction, imagery, a concrete word, figurative language, versions and typography of poetry.

a. Diction

Atar Semi reveals that diction is a word choice(1993). This opinion is similar to H. J. Waluyo Who argued that the poet is very careful in choosing words, because the written words should be considered the meaning. The composite side of the sound in rhyme and rhythm, the position of the word in the middle of the context of other words and the position of the word in the entire poem(2003). Referring to that opinion, the selection and use of words in poetry is an important aspect to be observed Right.

Jabrohim, Suminto and Chairul Saleh (2001) state that diction has an important role to achieve effectiveness in the 
writing of a literary work. The choice of words in poetry is closely related to meaning. It aims to communicate the poet's intention to the reader. Therefore, the words used in the poem should be chosen as carefully as possible by the poet. In addition, the poet also considers words used in poetry from various aspects and effects of pronunciation. H. J. Waluyo reveals that the words the poet chooses are poetic words in order to have a beauty effect (2003). Referring to that opinion, the poet uses the connotative words in his poetry which has more than one meaning. But still often found poets who use the words in everyday language. All of it aims to give beauty in his poetry and for readers to easily understand his work. In addition, poetry is also a revelation of the poet's flowing feelings which is poured in the form of beautiful words. Therefore, not infrequently the poets use the word typical of poetry and also clear words such as language that usually use every day in his poems

b. Imagery

Imagery can be defined as a word or the arange of word that can make fantasy or imagination according to Kosasih. E (2008). With the imagination, the readers as feel, hear and see like the dilivered by the poet. Imagery can be divided into three, namely sound image (auditive), visual image (visual), and touch or touch image (tactile image). Atar Semi (1993) argued that imagery is the arrangement of word raises the meaning of abstract be concrete and accurate. With the clear illustration can make the readers easy to enter to the atmosphere created.

c. Concrete Word

H. J. Waluyo (2003) reveals that every poet is trying to express what the poet wants to say. It aims in order to the reader to imagine with more life what is the poet describing. In relation to that opinion, every poet has the way of using different concrete words. The concretized is related the imagination, symbol and figurative. Concrete words are also called words that can be captured by the senses that allow the appearance of images. If the poet is skilled to concretize of the word, the readers can be clear to imagine the event or situation that the poet's described. The concretized is the effort of the poet to clarify his unimpeded attitude

d. Figurative language

According to $\mathrm{H}$. J. Waluyo (2003), figurative language is the language used by the poets in stacked or framed. This opinion is accordance with Jabrohim, Suminto and Chairul Saleh (2001), they state that figurative language is also called a figurative that commonly used to make a live of the described for Concrete and more express the feelings in the raised. From the opinion it can be aware that the figurative 
language used by the poet to say something by the used of figurative, indirectly express the meaning. Majas are used to convey the feelings, hopes, moods, and passions of his life so that poets avoid the limitations of denotative words meaningfully straightforward.

From the opinion above the researcher that the figurative language can be used to say some words by the figurative, that is reveal the meaning indirectly. The poet used the figurative language to avoid the limitation of denotative which has real meaning.

e. Verification

Verification is the modification consists of rhyme, rhythm, and poetic meter. Marjorie Boulton In H. J. Waluyo mentions rhyme as phonetic form (2003). Rhyme is a sound equation in poetry, both at the beginning, middle, and end of the line of poetry. H. J. Waluyo (2003) suggests that repeated sound equations can create concentration and strength of language or often called the magic word.

Rhythm is closely related to sound and is also associated with repetition of sounds, words, phrases, and sentences. The rhythm in poetry arises because the repetition of sounds is successive and varies, for example the final rhyme, assonance, and alliteration. The rhythm is also caused by weakly lethal word stresses, caused by the properties of the consonant and the vowel or the short length of the word. Herman J. Waluyo (2003) states that the rhythm of repetition of sounds, words, phrases, and regular sentences of a line of poetry lead to regular waves and create beauty.

Herman J. Waluyo (2003) states that the poetic meter in poetry is a repetition of fixed word pressure. The opinion is in line with Djoko Pradopo who revealed that the metrum is a fixed rhythm. That is, the turn is fixed according to a certain pattern (1990). This is caused since the amount and tension of sylable constantly therefore the increasing and decreasing sound is constant. Djoko Pradopo also revealed that the feels like having a poetic meter, that is traditional poem. This is caused since the amount of syllables in each line of the stanza and pattern of the rhyme(middle and last) constantly. Herman J. Waluyo (2003) states that the metrum in poetry is difficult to determine.

f. Typography

Atar Semi suggested that typography is also called form carving (1993). Typography is defined as an arrangement of lines, stanzas, phrases, words and sounds to produce a physical form capable of supporting the content, taste, and atmosphere of poetry. Poems are created to build the stanza. The poet is trying to create a poem like a picture called a 
concrete poem because of its facial order to form an image that represents a certain purpose.

Therefore, poetry is also a revelation of the poet's flowing feelings which is poured in the form of beautiful words and there are concrete words that can be captured by the senses that allow the appearance of images. In writing Poetry need too majas to convey the feelings, hopes, moods, and passions of his life so that poets avoid the limitations of denotative words meaningfully straightforward. The last, need a rhythm to related the sound and is also associated with repetition of sounds, words, phrases, and sentences to make a beautifully of poetry.

\section{Inner Structure of Poetry} mandate.

The inner poetry's structure are themes, feeling, tone and

a. Themes

H.j Waluyo (2003:106) states that theme is the subjectmatter proposed by the poet through his poetry. From the opinion it can be seen that the theme is the idea of the poet in his poems. The central idea of the matter or mind is so strongly urged in the poet's soul that it becomes the main foundation of his pronunciation. The theme is the central idea implicit in the entire contents of the poem. The feeling expressed are depiction of the inner atmosphere. Themes can be divide into diverse, e.g. Godhead (religious), love, solidarity, patriotism, struggle, failure of life nature, justice, social criticism, democracy, and so on.

b. Feeling

The poet has a certain attitude towards reader. The poet's attitude to the reader is called the tone of poetry. H.J. Waluyo stated that the tone is the poet's attitude towards readers (2003). Referring to that opinion that tone in the poem is made by the poet to give rise to a certain atmosphere. The atmosphere of poetry is felt by the reader as a result of the poet's tone. H.J. Waluyo (2003) reveals that there is a cynical poem, protest, patronize, rebel, playful, serious, patriotic, compassionate, fearful, gripping, casual, ignorant, pessimistic, humorous, mocking, charismatic, philosophical, Solemn, and so on. Referring to that opinion, from the compassionate tone created by the poet in his poetry can create an air of compassion for the reader as he reads the poet's work, and so on. In addition, through the tone, the reader can know the submission of the poet is either impressed patronizing, advising, mocking, relaxing, etc. or being straightforward just to tell something to the reader.

c. Tone

Poetry is the literature that best represents expression the poet's feelings. Therefore, the poet is creating a poem has 
different feelings. Feelings of the poet (feeling) is the inner feel of the poet who expressed with full appreciation and the right dose so expected poetry created poet was alive, touching emotion, and thrilling. Feelings are participated expressed and should be appreciated by the reader. The tone and feeling of the poet will more captured if the poem is read aloud inn reclamation. Herman J. Waluyo (2003:40) states that the feeling that animates poetry can be a feeling of joy, sadness, tears, alienation, offense, heartbreak, arrogance, grief, jealousy, loneliness, fear and regret

d. Mandate

A massage is an impression that the reader sees after reading a poem. The message, order, or advice to be conveyed by the poet can be examined after the theme, taste, and tone of the poem are understood (Herman J. Waluyo, 2003). Referring to that opinion, the message in poetry cannot be separated from the theme and contents of poetry proposed by the poet. In addition, the mandate is an impression captured by the reader after reading poetry. After reading the poem,

The reader will be able to deduce the peom's message. The poem's passage also relates to the reader's perspective on something.

Form the discussion can be said theme is the main idea of the poems to make foundation of pronunciation to know the background of the poems and covey with the tone to led the certain atmosphere. The poet used the feeling to make the poetry more memorable life and the reader can take the mandate clearly.

\section{Invictus}

Invictus, meaning "unconquerable" or "undefeated" in Latin consist of four stanzas and sixteen lines, the rhyme scheme is ababcdcd-efef-ghgh it is a poem by William Ernest Henley. The poem was written while Henley was in the hospital being treated for tuberculosis of the bone, also known as Pott's disease. As he healed in the infirmary, Henley began to write poems, including "Invictus," which concludes with the oft-referenced lines "I am the master of my fate" I am the captain of my soul." Henley's poems often engage themes on inner strength and perserverance. The poem is written in 1875 and published in 1888. The poem was originally untitled, but in 1900 Arthur Quiller Couch included the poem along with the title "Invictus" in his book The oxford Book of English Verse. In order to completely understand the meaning of this poem, it is important to know the life of William Ernest Henley. As young boy, Henley developed tuberculosis. Of the bone. At the age of 25, the tuberculosis spread to his foot. Physicians decided that in order to safe Henley's life, the must amputate his leg below the knee. While in the hospital bed, Henley wrote the poem Invictus. 


\section{Research Methodology}

\section{Design of the Research}

In this research, the researcher used descriptive qualitative method. The researcher would try to analyze the data and make a description about the Structure of Invictus. According to Gay (2000), qualitative methods involve the collection and analysis of primarily non numeral data obtained from observation, interviews, tape recording, and document. By applying this research method, the researcher would try to describe and interpret the current problem based on the accurate data. This research deals with the poem of William Ernest Henley.

\section{Data Collection Method}

Evidence helps provide answers to the research questions. To get these answers, the researcher engage in the step of collecting or gathering data. Collecting data means identifying and selecting individuals for a study, obtaining their permission to study them, and gathering information by asking people question or observing their behaviors (Fraenkel 2005)

Therefore, the researcher used the documentation such as the process of classifying and annotating texts, photographs, like arranged the collection and documentation of photographs as the object in data collection method.

In doing this research, there are some steps used by the researcher in collecting the data. First, the researcher read the poem Invictus of William Ernest Henley. Second the researcher analyzed the structure of poetry used in the poem. Third, the data were arrangement based on the types of structure

\section{Data Analysis Method}

the researcher used objective approach. Objective approach is an equation to be optimized given certain constraints and with variables that need to be minimized or maximized using nonlinear programming techniques. The objective approach to interpretation means the court interprets the words or conduct according to what it would lead a reasonable person to believe. The objective approach is distinct from the subjective approach in that it does not consider the actual or 'inner' desires and opinions of the party, but simply what it outwardly manifests. In this case the researcher can be use the objective approach to Analysis the Structur of Invictus

\section{Research Finding}

The physical structures of Invictus are inter-related each other. The connection of structures and invictus is to build a great poem. The research's results of physical structures in Invictus are a. Diction

In Invictus the poet used poetic words in the first stanza Out of the night that covers me, Black as the pit from pole to pole and last stanza it matters not how strait the gate 
The word night in the first stanza is the word to describe how the dibble of the dark night that he felt. The word in the next line black as the pit is the words to support the first line to make the readers imagine his felt about everything in the black as a symbol of hopeless and depressed

In the last stanza the poet wrote it matter not how strait the gate. It conveyed no matter how really hard to survived, but he will walk on and words the gate is the symbol of the hard way to get better life after it.

b. Imagery

Imagery in this poem is strong very much. There are two kinds of imagery which can be found in the poem. They are tactile and visual images. These images are formed by the diction which is used by the poet. The poet invited the readers to feel, see and hear what the poet felt. The tactile images can be viewed from the quotes

c. Concrete word

The concrete words which are used by the poet in his poetry aim to make the readers reflect on the poet's means and make the poetry is more alive. It can be seen in the used of the concrete word in the poem. The poet used words "not cried aloud" and "me unafraid."

d. Figurative Language

the poet used two figurative languages, they are personification and parallelism. Personification is a figurative language that gave the characteristic of human to the noun while parallelism is a figurative language that repeated the words in the same lines in one stanza.

e. Verification

The poet used it to create the concentration and the strength language with rhyme, then he gave the rhythm with the repeating sound with the regularly sentences to create regularly phase and beauty.

\begin{tabular}{l|l|l}
\hline $\begin{array}{l}\text { Physical } \\
\text { Structure } \\
\text { Diction }\end{array}$ & $\begin{array}{l}\mid c \\
\frac{\text { the first stanza }}{\text { Out of the night that covers me, }} \\
\text { Black as the pit from pole to pole } \\
\text { stanza is the word to } \\
\text { describe how the dibble } \\
\text { of the dark night that he } \\
\text { felt } \\
\text { black as the pit is the } \\
\text { words to support the first } \\
\text { line to make the readers } \\
\text { imagine his felt about } \\
\text { everything in the black as } \\
\text { a symbol of hopeless and } \\
\text { depressed }\end{array}$ \\
\hline \begin{tabular}{l} 
it matters not how strait \\
\hline
\end{tabular}
\end{tabular}




\begin{tabular}{|c|c|c|}
\hline \multirow[t]{2}{*}{ Ayu Malinda } & \multicolumn{2}{|r|}{ Lunar Vol. 2 No.1 May, 2018.} \\
\hline & It matters not how strait the gate & $\begin{array}{l}\text { the gate. It conveyed } \\
\text { no matter how really hard } \\
\text { to survived, but he will } \\
\text { walk on } \\
\text { the gate is the symbol of } \\
\text { the hard way to get } \\
\text { better life after it }\end{array}$ \\
\hline \multirow[t]{2}{*}{ Imagery } & $\begin{array}{l}\text { Beyond this place of wrath and tears } \\
\text { Looms but the Horror of the shade, } \\
\text { And yet the menace of the years } \\
\text { Finds, and shall find, me unafraid }\end{array}$ & $\begin{array}{l}\text { From the quotations the } \\
\text { poet looked into the } \\
\text { future about the anger } \\
\text { and the pain that he felt } \\
\text { in his life, particularly in } \\
\text { the places such as the } \\
\text { hospital. The words horror } \\
\text { of the shade described } \\
\text { that the hospital became } \\
\text { the hellish place }\end{array}$ \\
\hline & $\begin{array}{l}\text { Out of the night that covers me, } \\
\text { Black as the Pit from pole to pole, } \\
\text { I thank whatever gods may be } \\
\text { For my unconquerable soul }\end{array}$ & $\begin{array}{l}\text { The visual images } \\
\text { the sentence Out of the } \\
\text { night that covers me } \\
\text { described that the poet } \\
\text { wants the reader to } \\
\text { imagine that the poet in } \\
\text { the night and the dark } \\
\text { was covers everything in } \\
\text { a black. He cannot be } \\
\text { seen everything that can } \\
\text { be symbolized as } \\
\text { hopeless and depression } \\
\text { in his soul which is lost }\end{array}$ \\
\hline $\begin{array}{l}\text { Concrete } \\
\text { word }\end{array}$ & not cried aloud" and "me unafraid. & $\begin{array}{l}\text { by the using it, the poet } \\
\text { wants to show that the } \\
\text { words have the real } \\
\text { meaning not figurative. } \\
\text { The concrete word that } \\
\text { the poet used to make his } \\
\text { poetry is easier to } \\
\text { understand. } \\
\text { additional of the } \\
\text { concrete words are to } \\
\text { make the reader to } \\
\text { imagine more vividly } \\
\text { what is mean in his poetry }\end{array}$ \\
\hline $\begin{array}{l}\text { Figurative } \\
\text { Language }\end{array}$ & Out of the night that covers me & $\begin{array}{l}\text { The poet makes word the } \\
\text { night as something which } \\
\text { is life and it can cover the } \\
\text { poet. It told the readers } \\
\text { that in the night, the dark }\end{array}$ \\
\hline
\end{tabular}




\begin{tabular}{|c|c|c|}
\hline & & $\begin{array}{l}\text { was cover him and make } \\
\text { everything in a black. The } \\
\text { night is a symbol of } \\
\text { hopeless and depression } \\
\text { of losing a soul and } \\
\text { cannot see the future }\end{array}$ \\
\hline & $\begin{array}{l}\text { I am the master of my fate and I am } \\
\text { the captain of my soul }\end{array}$ & $\begin{array}{l}\text { That was used the } \\
\text { parallelism in repeating } \\
\text { the word I am to } \\
\text { emphasized the meaning } \\
\text { of the words. The words } \\
\text { have meaning that he is } \\
\text { the one who know about } \\
\text { herself and he decides } \\
\text { what he wants to do } \\
\text { freely }\end{array}$ \\
\hline & $\begin{array}{l}\text { covers me, pole to pole, may be, } \\
\text { soul; circumstance, cried aloud, } \\
\text { chance, but unbowed; tears, } \\
\text { shade, years, unafraid }\end{array}$ & $\begin{array}{l}\text { In Invictus the poet used } \\
\text { the rhyme, rhythm and } \\
\text { poetic meter. The rhyme } \\
\text { scheme is abab-codcd- } \\
\text { efef-ghgh. It can be seen } \\
\text { from the first stanza }\end{array}$ \\
\hline & $\begin{array}{l}\text { the gate, the scroll, my fate, and my } \\
\text { soul } \\
\text { lam the master of my fate } \\
\text { lam the captain of my soul }\end{array}$ & $\begin{array}{l}\text { The poet used it to create } \\
\text { the concentration and } \\
\text { the strength language } \\
\text { with rhyme, then he gave } \\
\text { the rhythm with the } \\
\text { repeating sound with the } \\
\text { regularly sentences to } \\
\text { create regularly phase } \\
\text { and beauty }\end{array}$ \\
\hline Typography & & $\begin{array}{l}\text { the poet used } \\
\text { typography for writing } \\
\text { every line in Invictus. The } \\
\text { typography can be seen } \\
\text { by using the punctuation } \\
\text { (drop and comma). By } \\
\text { using of punctuation, it } \\
\text { can make the poetry look } \\
\text { beautiful and also make } \\
\text { stressed in reading, so the } \\
\text { readers can read the } \\
\text { poem easily and always } \\
\text { interested to read it }\end{array}$ \\
\hline & & \\
\hline
\end{tabular}




\section{Discussion}

Based on the data analysis, the poet found two structures in Invictus. In making the poetry, the poet used the structure of poetry in the way they express their feeling or to make the poetry more interesting and alive. The structure is divided into two sections that are physical structure and inner structure.

The physical structure, the first found is the dictions. The researcher found the diction in the first and the last stanza. In the first stanza, the word night is the word to describe how the dibble of the dark night that he felt. The words in the next line black as the pit is the words to support the first line to make the readers imagine his felt about everything in the black as a symbol of hopeless and depressed. In the last stanza, the words the gate is the symbol of the hard way to get better life after he passed the trial.

The second is the imagery, it was divided in tactile and visual images in the poem were added all of type of imagery that has purposed to make the readers easier to imagine how the poet felt at the time. Ffurthermore, the concrete word, the poet using it too and it found in some lines of the stanza to made the readers knew the poet means clearly. The figurative language added too in this poem in some lines, it is purposed to beautify the poem. In verification the poet used the rhyme, rhythm and poetic meter to emphasize the meaning of the poem. It can beseen in the last stanzas that the poem was using the repeating words to make the emphasized there. The last is typography; the poet made the poem by his felt not used the rules and certain system. That can be called the conversional typography.

The inner structure only divided in the four sections. They are theme, tone, feeling and mandate. The poet was using it in the poetry to make the readers get the point of the poetry and get the message or moral value that explains in the poetry. The theme fight to survive is taken of the real in his life so the poetry became more alive. The tone was used to make the certain situation to support the theme. The atmosphere that make the situation felt seriously. From the tone of poetry which made a mercy, serious, and anger situation the readers can imagine the feeling of the poet. The last is the mandate, the poetry can be lesson to the readers make the readers not felt meaningless after read the poetry and they can take some moral value to increase some knowledge from the poetry. The only purposed is how the readers enjoyed the poetry and they can felt the message or some explanations that the poet want to tell by the poet or the poem.

Out of the night that covers me describes the troubles of his early life. He is covered pole to pole with something terrible. Luckily, his soul is unhindered. In the fell clutch of circumstance continues the story. He has high spirits, regardless of what has happened. He was bruise, but he is not ashamed. The third stanza states that even though he may not know what is to come, he is unafraid and ready 
for life. The last stanza states that even though his future may be established to the disease, he will continue on and control his own fate and soul with whatever time he has.

\section{E. Conclusion}

To make a great poem, the poet need some structure. The structure of poetry is consisting of two structures, namely; physical structure and inner structure. The physical structure consists of six sections, they are diction, imagery, concrete word, figurative language, version and typography. While, the inner structure is divide on four proportion they are theme, tone, feeling and mandat.

In the end, the researcher expects that this study would be a valuable asset of reference for generations to come who conduct more advanced study in studying literature especially in the structure of poetry.

\section{F. Acknowledgement}

First of all, the researcher would like to thank to Almighty God Allah S.W.T, for his everlasting blessings. Peace and blessing are upon her beloved prophet, Muhammad S.A.W and all of his family.

Secondly, I would like to express my greatest appreciation and sincere gratitude to those who have supported for their invaluable guidance and correction in the course of the undertaking and writing of this thesis:

1. Drs. H. Teguh Sumarno, MM. as The Rektor of PGRI University of Banyuwangi

2. Abdul Munir, M.Pd. the dean of Faculty of Language and Art at Unversity of PGRI Banyuwangi

3. Wulan Wangi, M.Pd. the head of English Education Department of Faculty of Language and Art at University of PGRI Banyuwangi

4. Wulan Wangi, M.Pd. as the first consultant and Yuli Sugianto, M.Pd. as the second consultant for their invaluable guidance and constructive suggestions for the completion of this writing.

5. My mother and my friends for their support and sacrifice.

Any shortcoming, lack of information and mistakes in the thesis both in terms of techniques and contents are responsibility of the writer.

\section{G. Reference}

Buckley, Jerome Hamilton. William Ernest Henley: A Study in the CounterDecadence of the Nineties. Princeton: Princeton University Press, 1945.

Cohen, Edward H. The Henley-Stevenson Quarrel. Gainesville: University of Florida Press, 1974.

Connell, John. W. E. Henley. London: Constable, 1949. http://www.victorianweb.org/authors/henley/introduction.html

Ross, John D. Henley and Burns. Port Washington, NY: Kennikat Press, 1970. Sayuti, Suminto A. 1996. Apreiasi Prosa Fiksi. Jakarta:Depdikbud. 
Siswantoro, Wahyudi. 2008.Pengantar Teori Sastra. Jakarta: Grasindo.

Pradopo, Rachmat Djoko. 2000.Pengkajian Puisi Analisis Sastra Norma dan Analisis Struktural dan Semiotik.Yogyakarta: Gajah Mada University Pers.

Waluyo, Herman J. 1987: Teori dan Apresiasi Puisi. Jakarta: Erlangga.

Buckley, Jerome Hamilton. William Ernest Henley: A Study in the Counter- Decadence of the Nineties. Princeton: Princeton University Press, 1945.

Cohen, Edward H. The Henley-Stevenson Quarrel. Gainesville: University of Florida Press, 1974.

Connell, John. W. E. Henley. London: Constable, 1949.

Davidson, Donald. British Poetry of the Eighteen-Nineties. Garden City, NY: Doubleday, Doran, 1937.

Frawley, Maria H. Invalidism and Identity in Nineteenth-century Britain.

Chicago: The University of Chicago Press, 2004 meyyer, Jim. 1997. What is litterature.University of North Dakota

Moran, Jessica. 2003. Literary culture in history. Berkeley:university California Olilla and Jantas, 2006. deffinition of poetry

Patrick, Suppes. 2009. Rhytm and meaning in poetry

Reymond williams. 1977marxism and literature. New york:oxford New York

Wellek and Warren. 1989. theory of literature. New York:harcourt, brace and company

\section{INVICTUS}

Out of the night that covers me,

Black as the Pit from pole to pole,

I thank whatever gods may be

For my unconquerable soul.

In the fell clutch of circumstance 
I have not winced nor cried aloud.

Under the bludgeonings of chance

My head is bloody, but unbowed.

Beyond this place of wrath and tears

Looms but the Horror of the shade,

And yet the menace of the years

Finds, and shall find, me unafraid.

It matters not how strait the gate,

How charged with punishments the scroll.

I am the master of my fate

I am the captain of my soul 